\author{
ks. Michał Drożdż \\ Uniwersytet Papieski Jana Pawła II w Krakowie
}

\title{
TROSKA O LUDZKIE OBLICZE MEDIÓW - OD REDAKCJI
}

W czasie III sesji soborowej 4 grudnia 1963 roku ojciec święty Paweł VI wraz z ojcami soborowymi podpisał Dekret o środkach społecznego przekazywania myśli Inter mirifica. Od tamtego czasu minęło 50 lat, kiedy Kościół w tym dokumencie soborowym nie tylko dostrzegł i docenił wartość mediów jako godnych podziwu narzędzi komunikowania się ludzi, ale pokazał także nowe drogi ewangelizacji przy pomocy środków społecznego przekazu i komunikowania myśli. Dlatego tematem wiodącym dziewiątego numeru naszego czasopisma „Studia Socialia Cracoviensia” jest Społeczeństwo medialne. Analizy zawarte w kolejnym numerze naszego pisma są owocem naukowej refleksji nad tym ogromnym dziedzictwem relacji Kościoła do mediów, dziedzictwem zainspirowanym na nowo przez dekret soborowy Inter mirfica.

Dekret Soboru Watykańskiego II Inter mirifica zapoczątkował rozwijane później przez Kościół pozytywne patrzenie na świat mediów i jego troskę o ludzkie oblicze mediów. Jest to także zadanie dla uniwersytetów i ośrodków badawczych, pokazujących stan i perspektywy rozwoju społeczeństwa medialnego. Media są bowiem przestrzenią życia współczesnego społeczeństwa w jego wielorakich wymiarach i płaszczyznach, przede wszystkim w kontekście kondycji i rozwoju współczesnej rodziny. Mediów nie można traktować jako rzeczywistości obcej, ponieważ wszyscy jesteśmy w różnym stopniu i charakterze włączeni w świat mediów. Świat mediów jest bez wątpienia światem człowieka oraz integralną częścią współczesnej kultury. Historia i współczesność kultury pokazują, że nie może istnieć integralna, w pełni ludzka kultura bez odpowiedniego etosu, odpowiadającego prawdzie o człowieku i porządku aksjologiczno-moralnym. Stąd też wynika podstawowe wyzwanie i zadanie, by etos mediów był zintegrowany z etosem ludzkiego życia albo przynajmniej pozytywnego świata wartości nie niszczył. Analizy zawarte w prezentowanym numerze podejmują to zadanie badania procesów kształtujących społeczeństwo medialne, ze szczególnym uwzględnieniem wymiaru aksjologicznego tych procesów.

We wszelkich ocenach stanu i rozwoju społeczeństwa medialnego trzeba zachować krytyczne spojrzenie. Należy się strzec generalizujących tez, a nierzadko również sloganowych haseł, przypisujących mediom wszelkie możliwe zło, ale także nie można 
się bezkrytycznie zachwycać nowymi możliwościami technologii medialnych i skutecznością ich oddziaływania na człowieka bez uwzględnienia ich negatywnych skutków i dysfunkcji. Media wpływają znacząco na kształt społeczeństwa, które można określić w dobie rozwoju cywilizacji informacyjnej jako „społeczeństwo medialne”.

Zadaniem naszego czasopisma „Studia Socialia Cracoviensia” jest prezentować rzetelne naukowe badania szeroko rozumianych problemów i zjawisk współczesnego społeczeństwa medialnego. Prezentacja tych badań ma na celu nie tylko upowszechnianie owoców badań naukowych, wymianę doświadczeń i wzorców badawczych; ma także cele praktyczne. Ambicją redakcji i autorów artykułów jest odkrywanie pozytywnych trendów społecznych i inspirowanie praktyki medialnej, praktyki pracy socjalnej czy praktyki życia rodzinnego pozytywnymi wartościami i ideami służącymi dobru człowieka i społeczeństwa. Ta inspiracja czerpie z bogatego dziedzictwa myśli i działań bł. Jana Pawła II. W takim duchu troski o człowieka we współczesnym społeczeństwie medialnym należy odczytać jego ostatnie przesłanie z listu apostolskiego Szybki rozwój: „nie lękajcie się nowych technologii! Są one «pośród niezwykłych wynalazków» (Inter mirifica, 1), które Bóg dał nam do dyspozycji, abyśmy mogli odkrywać prawdę, korzystać z niej i ją przekazywać, również prawdę o naszej godności i o naszym przeznaczeniu"'. Te słowa można traktować jako duchowy testament, który pozostawił Jan Paweł II, szczególnie ważny w czasie rozwoju społeczeństwa medialnego. Jan Paweł II fascynował media swoja osobą. Jego głębokie umiłowanie prawdy, ewangeliczna prostota stały się źródłem szacunku, jaki zdobył w świecie mediów. Nie tracił tego szacunku i nie przestawał być autorytetem nawet wtedy, kiedy nie szczędził krytyki pod adresem mediów, jeśli sprzeniewierzały się prawdzie, dobrym obyczajom i godziły w podstawowe wartości ogólnoludzkie. Zawsze jednak zachęcał dziennikarzy do wsłuchiwania się w problemy człowieka i do obrony jego praw, do bycia rzecznikami spraw ludzkich, przekazywania prawdy o człowieku i jego godności.

Mamy nadzieję, że prezentowane w tym numerze artykuły poszerzą horyzonty wiedzy naszych czytelników i przyczynią się także do twórczego dialogu we współczesnym społeczeństwie medialnym na fundamencie uniwersalnych wartości, służących dobru człowieka i społeczności.

redaktor naczelny

ks. Michał Drożdż

1 Jan Paweł II, List apostolski Szybki rozwój, 14. 